\section{Globale helsekampanjer og det nasjonale helsevesen}

Mer penger enn noen gang tidligere er blitt gitt til kampen mot sykdommer som aids, tuberkulose og malaria i utviklingsland. Men siden helsevesenet i mottakerlandene er lite utbygd og mangler midler, er virkningen av kampanjene blandet. Det er konklusjonen i en rapport fra Verdens helseorganisasjon, publisert i The Lancet (1).

Rapporten omhandler fire ledende globale helsekampanjer: The Global Fund to fight AIDS, Tuberculosis and Malaria, The US President's Emergency Plan for AIDS Relief (PEPFAR), Global Alliance for Vaccines and Immunization (GAVI) og Verdensbankens Multi-Country AIDS Program. Midler fra disse har hjulpet millioner av mennesker, men også hatt negative effekter på helsevesenet i de berørte landene.

I mange fattige land har flere fått behandling på grunn av de globale kampanjene, som ofte har styrket primærhelsetjenesten i lokalsamfunn.

Men økte midler til spesifikke intervensjoner støttet av globale helsekampanjer har ikke gitt flere helsearbeidere. I noen tilfeller har det ført til større forskjell mellom urbane og rurale områder og resultert $i$ at helsearbeidere har gått fra det offentlige helsevesenet og over i prosjekter. I blant annet Kenya og Zambia fant forskerne bevis for at helsepersonell gikk fra det offentlige for å arbeide for globale helsekampanjer på grunn av bedre arbeidsvilkår og høyere lønn. Det trengs større innsats for å løse mangelen på helsearbeidere ifølge forfatterne.

«Konklusjonene i rapporten er motstridende, men det klare budskapet er at globale helsekampanjer har medført både fordeler og ulemper for det offentlige helsevesenet. Det er konsekvent blitt forsømt av helsekampanjene. Det er tegn på at dette er i endring, men vesentlig mer må gjøres for å styrke og måle hvordan helsekampanjer bidrar til helsesektoren generelt,» sier Richard Horton, redaktør i The Lancet, $i$ en pressemelding.

\section{Oda Riska}

oriska@hotmail.com

Tidsskriftet

\section{Litteratur}

1. Samb B, Evans T, Dybul M et al. An assessment of interactions between global health initiatives and country health systems. Lancet 2009: 373: 2137-69.

\title{
Global helse i medisinstudiet er viktig!
}

\author{
En seks måneder gammel jente er innlagt med pneumoni med kompli- \\ kasjoner. Hun sover, respirasjonsfrekvensen er høy, men faren er over \\ for denne gang. Hun er født med komplett atrioventrikulær septum- \\ defekt og det er nok ikke siste gang mor må oppsøke landsbysykehuset.
}

Ni medisinstudenter fra Universitetet i Bergen befinner seg høsten 2008 på et landsbysykehus utenfor Vellore i Sør-India. En lege legger frem jentas sykehistorie. Stetoskopene tas frem, og selv om vi ennå ikke er erfarne studenter, kan vi høre at hjertet ikke slår som det skal. Utenfor den fulle ettroms barneavdelingen spør legen oss hva som hadde skjedd dersom jenta ble født der vi kommer fra. Operasjon kan redde jenta, tenker vi - og oppfølging er nok viktig. Det er en stor påkjenning for foreldre at barna er syke, enten man er i Norge eller i India. Mennesker på landsbygda i India møter mange hindre før de kan være opptatt av de problemene norske foreldre med barn med hjertefeil står overfor. Pasienthistorien i denne artikkelen er satt sammen av ulike sykehistorier som vi fikk presentert under oppholdet i India.

\section{Kurs i global helse}

Høsten 2008 ble det for første gang i regi av Det medisinsk-odontologiske fakultet ved Universitet i Bergen tilbudt et studieprogram i global helse på 30 studiepoeng til 15 studenter med valgtermin, som er en «fritermin» mellom den prekliniske og den kliniske delen av medisinstudiet. Dette er et stort fremskritt i forhold til ukekurset i internasjonal helse som ellers står på timeplanen i løpet av seks studieår. Omfanget av undervisning i global helse er omtrent det samme ved de andre medisinske fakultetene i Norge. Målet med det nye kurset er å gi en grunnleggende forståelse av de store globale helseutfordringene verden står overfor. En seks ukers teoretisk del gis ved Senter for internasjonal helse, Institutt for indremedisin og Institutt for samfunnsmedisinske fag. Foredrag, gruppearbeid og diskusjoner om bl.a. sykdomsbyrde, etikk, antropologi, økonomi og helsesystemer forberedte oss studenter til den praktiske delen av kurset: hospitering på samarbeidsinstitusjoner i andre deler av verden. Av de 12 studentene som valgte å ta kurset, reiste tre til University of Botswana, og ni studenter

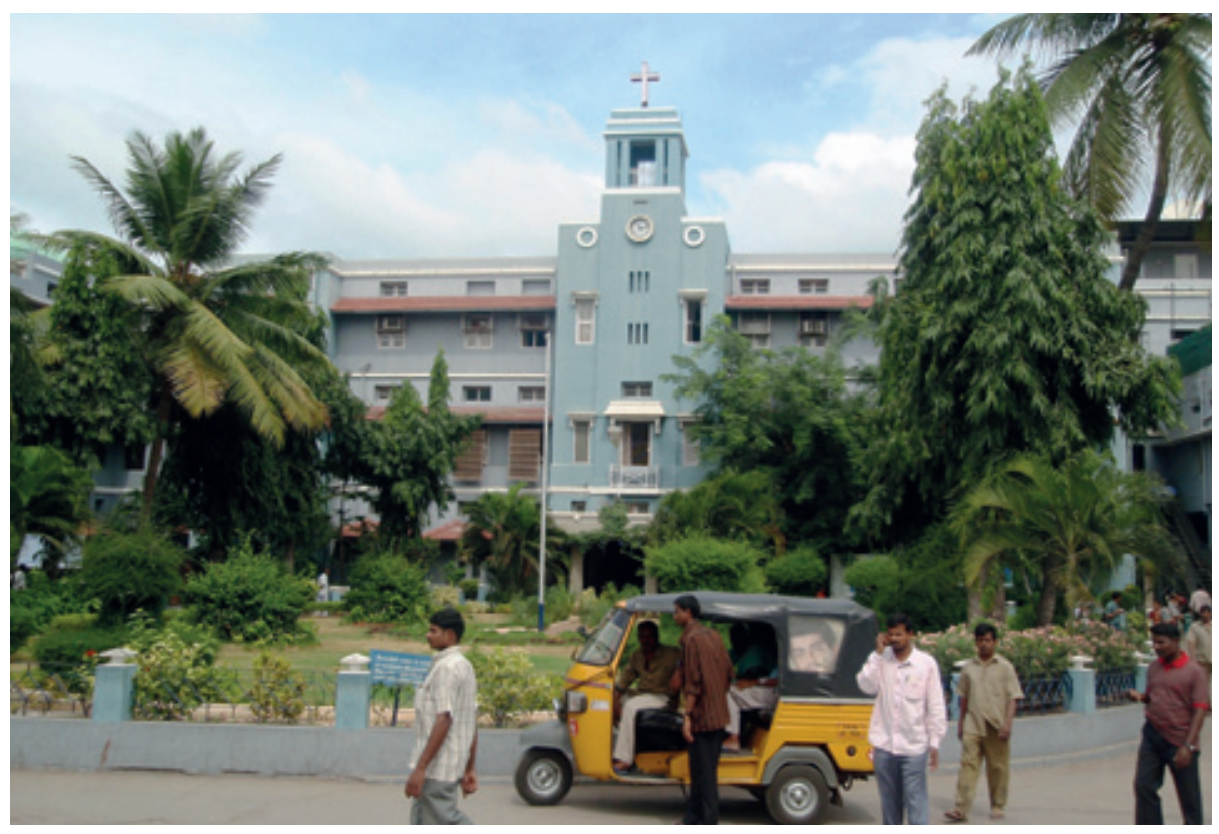

Hovedsykehuset ved Christian Medical College. Foto Anette Lodvir Hemsing 